\title{
Learning Losses Caused by the Covid-19 Pandemic - A Significant Threat to Economic Development
}

\author{
Tea Kasradze \\ Professor, Caucasus International University \\ Nino Zarnadze
}

Associate Professor, Caucasus International University

\section{Abstract}

Numerous studies show that there is a positive correlation between education and the economic development of the country. Strong education systems have a positive impact not only on the success of individuals but also on the economy of the entire country. Graduates equipped with the skills required by the labor market can easily find a place in this market. Knowledge and skills relevant to market demand increase productivity have a positive impact on economic growth and development. Unfortunately, Covid Pandemic has severely damaged the education systems. Governments, scientists, and experts provide us with statistical information daily around the world about both the slowdown in economic growth as a whole and the problems of individual sectors of the economy. These are the problems and numbers that are already visible and it can be said that the losses are easily measurable. However, the damage caused to the economy by education systems affected by the pandemic will be felt by countries and humanity years later, nor will it be easy to calculate. The problem is even more difficult in poor and developing countries. This paper aims to study the impact of the Covid Pandemic on the education system and economy in Georgia. The research examines the reports and studies of various international organizations, analyzing the secondary data obtained from them. Local policy documents, government reports and regulations, and papers of different researchers have also been studied, conclusions have been made and relevant recommendations have been developed.

Keywords: Covid-19 pandemic, school closures, economic growth, learning losses, employment, development

\section{Introduction}

We live in a high-tech era. Humanity has been able to achieve incredibly high results during its development. The development of techniques and technologies has provided a high rate of global production. Highly developed technologies have allowed humanity not only to use nature in its favor but to create alternative sources of nature, new forms, and means of communication. Modern civilization often referred to as technogenic civilization, is based on scientific-technical achievements. Today humanity can study brain cells at the level of neurons, do research on anti-cancer drugs, replace a bad gene with a good one, send an 
exoplanet hunter in space which monitors about 200000 near stars expecting to find thousands of new planets, create a solar-powered plane, which can stop in the air for 25 days, not to mention that today there are automobiles which can be driven without a man, and artificial intelligence, which participates in debates with people and wins, conducts interviews, assists disabled people and so on. Modern science achievements help humanity not only to solve current tasks but also have the potential to influence the development of humanity in the long-term perspective.

The creators of the above-mentioned scientific-technical achievements are highly developed countries, the so-called the most innovative countries - South Korea, Sweden, Singapore, Germany, Switzerland, Japan, Finland, Denmark, France, Israel, the United States, Austria, Ireland, Belgium, Norway, and others who put the largest financial and human resources in scientific researches and a practical realization of results (Kasradze, 2018). The vector of economic development of these countries is directed towards the creation of a knowledge economy in which a person, his/her knowledge, skills, and abilities have a central place. The model of the knowledge economy is one of the main reasons for their socio-economic development. The economy of knowledge as the highest stage of the post-industrial economy is the source of the growth of the country's economy and the level of public life (Kasradze \& Zarnadze, 2019).

Developed countries are spending huge financial resources to strengthen human capital since it is the main factor in creating new technologies, developing manufacturing, and increasing their efficiency. Human capital plays a major role in the development of science, culture, health, safety, and the social sphere (Wawrosz \& Mihola, 2013).

The developed countries put great resources in research and development. Different institutions of society are involved in this process: state, business, and research institutes. It should be noted that there is a great demand for researches and scientific findings all over the world. So, in developed countries, the number of people working in science, research, and development is increasing from year to year (Zarnadze \& Kasradze, 2019).

While global spending on research and development has reached a record high of almost 1.7 trillion US\$ and about 10 countries account for $80 \%$ of spending, on the other hand, $40 \%$ of the world population lives in poverty (Action against hunger, 2020); Two-thirds of the world's school-age children - or 1.3 billion children aged 3 to 17 years old - do not have internet connection in their homes (Unicef for every child, 2020); There are 258 million children and adolescents not in school (the total includes 59 million children of primary school age, 62 million of lower secondary school age and 138 million of upper secondary age) (Out-ofSchool Children and Youth, 2018); 617 million children and adolescents worldwide are not achieving minimum proficiency levels in reading and mathematics, even after several years of schooling. This means that more than one-half - 56\% - of all children won't achieve minimum proficiency levels by the time they should be completing primary education. The proportion is even higher for adolescents at 61\% (Data for the Sustainable Development Goals, 2017). Studies show that despite the increased access to education and although the problems of illiteracy are solved in developing countries, the quality of education by the current institutions can not be reflected in the development of a country (Kasradze, Tea; Antia, Vakhtang; Gulua, Ekaterine, 2019). 
Obviously, low-income countries are struggling with numerous problems on the path of education (Zarnadze \& Kasradze, 2019). But Covid Pandemic has made the problems of education even more acute. Nearly a quarter of a billion students worldwide are still affected by COVID-19 school closures, forcing hundreds of millions of students to rely on virtual learning. For those with no internet access, education can be out of reach. Even before the pandemic, a growing cohort of young people needed to learn foundational, transferable, digital, job-specific, and entrepreneurial skills to compete in the $21^{\text {st-century economy (Unicef }}$ for every child, 2020).

Some factors determine the level of education of the human (community): In this regard, a family needs to get educational materials, as well as the social status of parents, and the quality of their education, neighborhood, and the environment in general in which the person is placed (Gulua, 2017)

Covid Pandemic has exacerbated problems with access to education, funding, and quality around the world, especially in poor and developing countries. Which will harm the future economic development of the country and the welfare of the society. In our research, we try to prove the cause-effect links between learning losses caused by the pandemic and economic growth in Georgia. The research examines the reports and studies of various international organizations, analyzing the secondary data obtained from them. Local policy documents, government reports and regulations, legal acts, and papers of various researchers have been also studied, conclusions have been made and relevant recommendations have been developed.

\section{Education and Economic Growth - Literature Review}

The pathway from education to economics goes through the labor market (Zarnadze \& Kasradze, 2019). The education system has an important role in delivering quality labor resources that will positively affect economic growth and development. And the economy in turn is a prerequisite for improving the quality of education.

The closure of schools in early 2020 has led to learning losses around the world that will not be easily compensated for even if schools quickly return to their previous work environment. These losses will have a sustainable, long-term economic impact on both students and schoolchildren, as well as on society as a whole if timely and effective steps are not taken to address them.

When children lose out on education, they lose out on future opportunities including economic benefits, such as additional earnings, with far-reaching consequences (Psacharopoulos, Patrinos, Collis, \& Vegas, 2020). Some modeling suggests that the loss of learning during the extraordinary systemic crisis of World War II still had a negative impact on former students' lives some 40 years later (Ichino \& Winter-Ebmer, 2004).

COVID-19 aggravates the youth employment crisis. Even before the pandemic, more than 267 million of the world's 1.2 billion young people did not have employment, education, or training. Since the onset of the pandemic, one out of six young people has stopped working and working hours have been reduced by $23 \%$ for those still working. The pandemic is changing the global labor market in three ways, affecting youth: 1 . Reduces employment opportunities due to loss of COVID-related jobs; 2 . There are more obstacles to finding a job 
and moving on to better jobs; 3. Violation of education and training, which affects future employment opportunities (ILO, 2020).

Many examples of long-term school closures are not known in history before the Covid Pandemic, and therefore not much researches have been done to examine the damage caused by school closures to school beneficiaries and the economy. However, there is an interesting study conducted by Michèle Belot and Dinand Webbink in 2010 "Do Teacher Strikes Harm Educational Attainment of Students?". Where the results of long-term (up to 6 weeks and repeatedly) closure of schools due to a teachers' strike in Wallonia in the French-speaking southern region of Belgium have been studied. The study found that in this part of Belgium, compared to other parts of the country where schools were not closed for a long time, there was an increase in grade repetition due to low academic achievement and generally, low educational attainment. The rate of continuing education in higher education institutions was also low (Belot \& Webbink, 2010).

It is noteworthy that the closure of schools not only deals with the loss of knowledge but also reduces the existing knowledge and skills that should have been the basis of future knowledge and skills.

Several interesting scientific papers and studies and reports by international organizations have been published during the pandemic period, exploring the links between education, the workforce, and economic growth and development. Among them is the study "The Economic Impacts of Learning Losses" by Eric A. Hanushek and Ludger Woessmann" published in 2020, according to which while the precise learning losses are not yet known, existing research suggests that the students in grades 1-12 affected by the closures might expect some 3\% lower income over their entire lifetimes. For nations, the lower long-term growth related to such losses might yield an average of 1.5\% lower annual GDP for the remainder of the century. These economic losses would grow if schools are unable to re-start quickly (Hanushek \& Woessmann, 2020).

In the same study, the authors discuss two categories of damage received by closing schools. On the one hand, reduced income in the long run of the pupils and students whose educational process has been suspended in educational institutions. On the other hand, the losses from the slowdown in the economic growth of countries, because they will have to move forward with less-skilled workers, which will also affect the welfare of society. Education equips people with the skills that make them more productive at carrying out their work tasks, particularly in modern knowledge-based economies. Education also provides knowledge and skills that enable people to generate and apply new ideas and innovations that enable technological progress and overall economic growth (Hanushek \& Woessmann, 2020). Nations with more skilled populations grow faster.

Through the educational system, pupils/students develop cognitive skills of economic value. The education system provides them with skills that make them more productive, especially in a modern knowledge-based economy. Education also provides knowledge and skills that enable people to create and apply new ideas and innovations to achieve technological progress and economic growth.

Learning losses due to the pandemic have different impacts on revenue losses in different countries. Students' future opportunities in the labor market are influenced by cognitive skills measured by standardized tests. A study conducted by the OECD in 2011-2015 examined the 
relationship between individual incomes and test scores in the 32 highest-income countries. Research has shown that countries vary considerably in the economic rewards to higher skills. While workers in Singapore are estimated to receive $50 \%$ higher income if they have one standard deviation higher test score, the typical worker in Greece gains just 14\% more income with one standard deviation higher test score. For the United States, the comparable return to skill is $27 \%$, and for the average across all sampled countries, it is $23 \%$. Importantly, these relationships provide estimates of the impact of skill differences across the entire work life.

Based on these calculations, Eric A. Hanushek and Ludger Woessmann found that individual income losses due to learning losses are highest in Singapore and lowest in Greece.

Table 1 Lost individual income due to Corona-induced learning loss

\begin{tabular}{|l|l|l|l|l|}
\hline $\begin{array}{l}\text { Learning loss (school-year } \\
\text { equivalents) }\end{array}$ & $\begin{array}{l}\text { Pooled } \\
(0.232)\end{array}$ & $\begin{array}{l}\text { US } \\
(0.274)\end{array}$ & $\begin{array}{l}\text { Lowest } \\
\text { [Greece] } \\
(0.137)\end{array}$ & $\begin{array}{l}\text { Highest } \\
\text { [Singapore] } \\
(0.501)\end{array}$ \\
\hline 0.25 & $1.9 \%$ & $2.3 \%$ & $1.1 \%$ & $4.2 \%$ \\
\hline 0.33 & $2.6 \%$ & $3.0 \%$ & $1.5 \%$ & $5.6 \%$ \\
\hline 0.50 & $3.9 \%$ & $4.6 \%$ & $2.3 \%$ & $8.4 \%$ \\
\hline 0.67 & $5.2 \%$ & $6.1 \%$ & $3.0 \%$ & $11.1 \%$ \\
\hline 1.00 & $7.7 \%$ & $9.1 \%$ & $4.6 \%$ & $16.7 \%$ \\
\hline
\end{tabular}

Source: The Economic Impacts of Learning Losses, Eric A. Hanushek, Ludger Woessmann, OECD 2020

Higher educational attainment is reflected not only in the high individual but also in high national incomes as a whole. Basic cognitive skills, as measured by international comparative tests in mathematics and science, are perhaps the most important determinants of economic growth and, thus, the long-term well-being of society (Hanushek \& Woessmann, 2020). These results on the relationship between educational activity and economic growth can be used to calculate the economic cost of learning losses.

Table 2 Long-run loss in GDP due to Corona-induced learning loss

\begin{tabular}{|l|l|l|l|}
\hline $\begin{array}{l}\text { Learning loss (school- } \\
\text { year equivalents) }\end{array}$ & $\begin{array}{l}\text { In \% of discounted } \\
\text { future GDP }\end{array}$ & In \% of current GDP & $\begin{array}{l}\text { GDP decrease in } \\
\text { the year 2100 }\end{array}$ \\
\hline 0.25 & $1.1 \%$ & $52 \%$ & $1.9 \%$ \\
\hline 0.33 & $1.5 \%$ & $69 \%$ & $2.6 \%$ \\
\hline 0.50 & $2.2 \%$ & $103 \%$ & $3.8 \%$ \\
\hline 0.67 & $2.9 \%$ & $136 \%$ & $5.1 \%$ \\
\hline 1.00 & $4.3 \%$ & $202 \%$ & $7.5 \%$ \\
\hline
\end{tabular}

Source: The Economic Impacts of Learning Losses, Eric A. Hanushek, Ludger Woessmann, OECD 2020

The relationship between academic achievement and school closure in the United States is explored by Megan Kuhfeld, James Soland, Beth Tarasawa, Angela Johnson, Erik Ruzek, and Jing Liu in the study "Projecting the Potential Impact of COVID-19 School Closures on 
Academic Achievement". The paper examines the impact of school absenteeism due to various causes (heavy snow, hurricanes, and other natural disasters) and their closure due to the Covid Pandemic on academic achievement. After the closure of the schools, they switched to distance learning, but due to the lack of experience of distance learning of students as well as teachers, as well as less access to technology, the result of distance learning did not equate to the result of face-to-face learning. The MAP Growth assessment data of 5 million public school students from grades 3 to grade 8 (approximately $22 \%$ of the total number of students in this grade) is analyzed in the study for the 2017-2018 and 2018-2019 academic years (Kuhfeld, et al., 2020).

Based on a study of the impact of school absenteeism and closures on student outcomes in Mathematics and ELA (English language arts) for a variety of reasons, a projection of student achievement in the period from the first closure of schools in the spring of 2020 to the start of the 2020-2021 school year has been made. The study has shown that school closures resulting from weather or natural disasters provide an analog to school closures due to COVID-19. Under the COVID Pandemic projections, students were projected to end the abbreviated $2019-2020$ school year with roughly $63 \%$ to $68 \%$ of the learning gains in reading but only $37 \%$ to $50 \%$ of the average gains in mathematics compared to those of a normal school year. Under the Full Absenteeism projections, the story is even direr, with students in sixth and seventh grade projected to have ended the disrupted 2019-2020 school year with less than $30 \%$ of their typical learning gains in both mathematics and reading (Kuhfeld, et al., 2020).

\section{Covid-19 Pandemic, Learning losses and Economic Growth in Georgia}

For assessment of general education quality system the Program for International Student Assessment (PISA), the Progress in International Reading Literacy Study (PIRLS), the Trends in International Mathematics and Science Study (TIMSS) are used in Georgia. These studies show that the level of students' knowledge in Georgia was quite low even before the Covid Pandemic (Kasradze, 2018). In particular, according to PISA 2018, Georgian students lag behind students from almost all countries in the region in terms of academic results. According to these results, Georgia ranks 67 th out of 78 countries in mathematics, 71 st in reading comprehension, and 74th in natural sciences. The share of students in Georgia who failed to reach the baseline level of achievement- $48.7 \%$ is also high, while in OECD countries the figure is on average $13.4 \%$ (Galt \& Taggart, 2020).

The year 2020 completely changed the field of education not only in Georgia but all over the world, and unfortunately, it was not a change for the better. None of the countries, including the developed ones, were ready for the challenges. The main difficulty was related to the transition to distance learning due to the pandemic. Education specialists from around the world recognize that distance learning is an extreme and rather weak solution and that it is almost impossible to acquire and deepen knowledge through it. Especially for low school students.

The educational process was difficult in Georgia as well. The number and the duration of lessons both were reduced which resulted in backwardness and learning loss. We have this reality all over the world today and it is difficult to talk about how this loss will be compensated.

Every failure in secondary school is important because it is very difficult to fill it. Things are much better at higher education institutions because there are students who are highly 
adapted and mobilized (Zarnadze, Nino; Kasradze, Tea, 2020). However, studies show that serious shortcomings are there too that need attention. However, we believe that this is a separate research topic.

One of the main obstacles to the distance learning process was the lack of technical and digital competencies in teachers, students, and parents. Teachers found it difficult to adapt to the new platforms and manage them technically.

The Internet and digital technologies are vital to modern man. Under the pandemic, it has acquired even greater significance since for a large part of the population the educational and work processes under limited mobility are carried out remotely via the Internet. Naturally, the lack of Internet access in such conditions causes serious discomfort for people.

Very soon after the start of the pandemic, the Georgian government took effective steps to ensure the continuity of education. In particular, the Microsoft Teams learning platform was created for public schools. Virtual classrooms were created for all public school classes and subjects, and more than 580,000 Microsoft Office 365 user profiles (528,327 students and 52,124 teachers) were created for students and teachers. The steps were taken by the Government of Georgia to ensure the continuous process of education in the conditions of the pandemic were named by OECD as one of the best examples in the world. This is evidenced by the learning losses calculated by countries by the OECD for May 2020.

Figure 1 Days of schooling lost by mid-May 2020

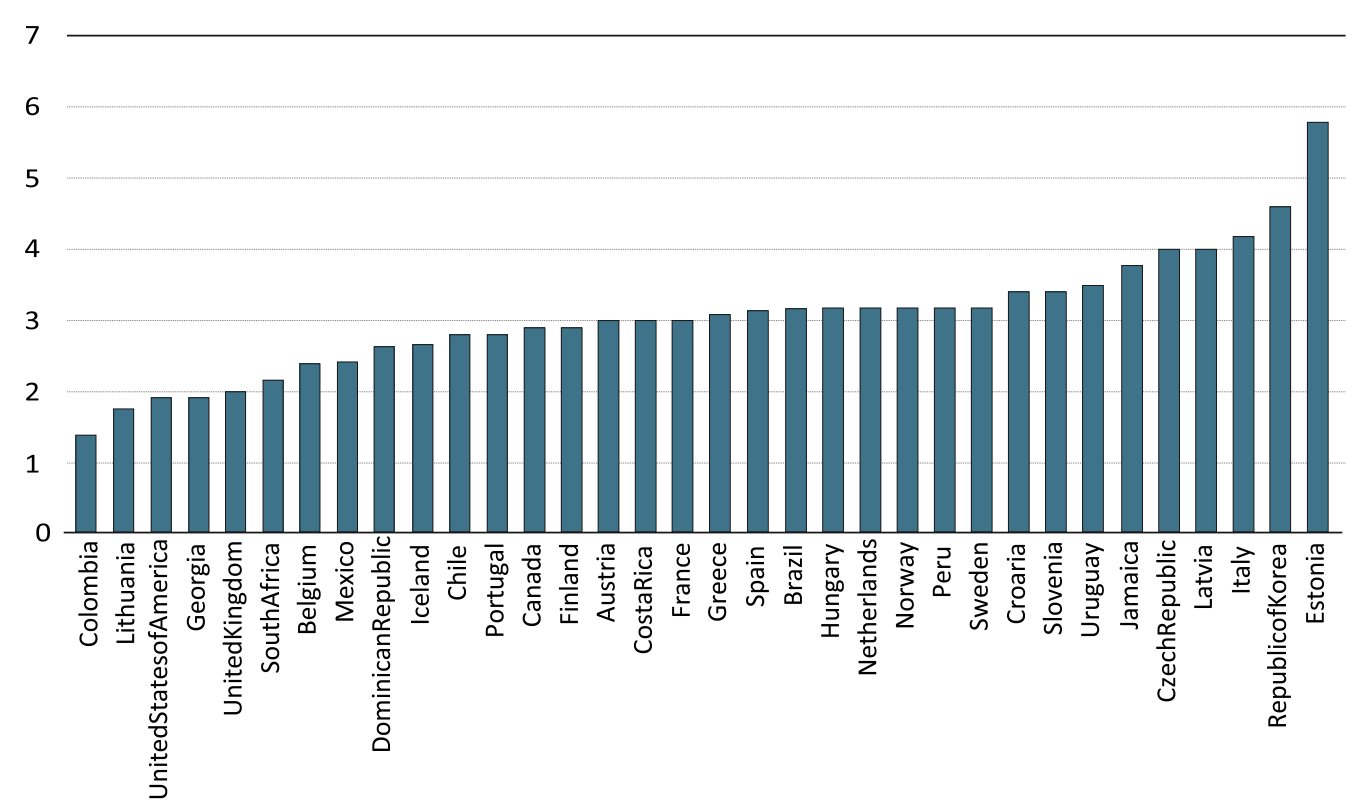

Source: The Economic Impacts of Learning Losses, Eric A. Hanushek, Ludger Woessmann, OECD 2020

Despite the government efforts, the problem of having access to the Internet and information technology has made access to education entirely a problem. The coronavirus brought to the 
surface the inequality that had already existed in education. Not only in Georgia but all over the world, it has put students with low economic opportunities in an unequal position and exacerbated the problem of access to education.

According to a joint report by the United Nations Children's Fund and the International Telecommunication Union published in December 2020, 15 percent of school-age children in Georgia did not have access to the Internet at home. This figure is two-thirds of school-age children in the world. The rate is similar among young people aged from 15 to 25 and equates to 759 million young people, or 63 percent (UNICEF, 2020).

According to the data of the International Telecommunication Union (ITU) in 2018, the citizens of Ukraine and Georgia had the lowest Internet access among the neighboring and Eastern Partnership countries - 63\%, while this figure was $81 \%$ in Russia, $79 \%$ in Belarus, $76 \%$ in Moldova, 71\% in Turkey and in neighboring Azerbaijan and Armenia it was $80 \%$ and $65 \%$, respectively (IDFI, 2020).

It should also be noted that Internet access is not the only indicator of its use. Computer literacy and digital literacy statistics are also important here. Only $62 \%$ of households in Georgia own a computer, while $46 \%$ of the population think they do not have the basic knowledge to use it.

According to the data of the National Statistics Office of Georgia in 2019, 79\% of households are provided with the Internet. In cities, this figure reaches $86 \%$. However, the situation is more deplorable in villages where only $69.9 \%$ of households have access to the Internet (IDFI, 2020).

According to the survey conducted by the Ministry of Education of Georgia in March 2020, 528,426 students were registered in the general education system, $12 \%$ of them $(63,272$ students) did not have access to the Internet at home, and 14\% (71,796 students) did not have computer equipment. One part of the other students had access to both fixed and mobile internet. Overall, out of these two overlapping groups, $88 \%$ of students had access to landline internet and $53 \%$ to mobile internet (Ministry of Education, Science, Culture and Sports of Georgia, 2020).

The OECD study is even more difficult. In particular, according to the survey, about $78 \%$ of students in Georgia own a computer suitable for school work. As for internet access, today up to 78,000 socially vulnerable students in Georgia do not have the internet. $95 \%$ of them live in the internet coverage area but are unable to pay internet fees due to material hardship (Reimers, Fernando M.; Schleicher, Andreas, 2020).

Although the above-mentioned restrictions on access to the Internet and digital technologies are present in Georgia today, the number of lessons and their duration in schools are reduced, most students and teachers do not have distance learning skills, the heads of the education system do not talk about learning losses, its future negative consequences and ways to compensate for the losses, and there are no relevant calculations. Therefore, we will try to predict the future personal/individual and economic losses caused by the pandemic-induced learning losses in Georgia by analyzing and generalizing the results of studies by international organizations and various foreign researchers.

According to the studies by Unicef conducted between July and October in 2020, an average of 40 school days were lost in countries where the academic year was already over by the time 
of the study due to school closures and distance learning gaps caused by the pandemic. Students in low-income countries missed more school days than students in high-income countries

Figure 2. Average days of school missed, by income level

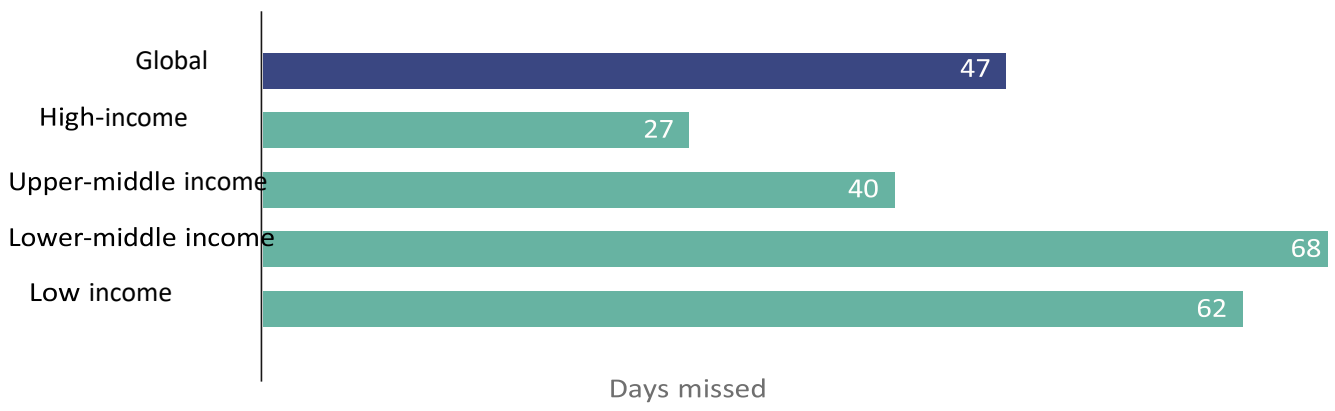

Source: UNESCO-UNICEF-World Bank joint survey round 2, 2020.

According to the New World Bank country classifications by income level 2020-2021, Georgia belongs to the upper-middle-income economies ${ }^{1}$, so we can assume that the number of days missed due to the pandemic in Georgia is about 40 school days (according to the national curriculum, there are 170 school days per year for II-XI graders) And 157 days (for I-XII graders)). Therefore, if we rely on Eric A. Hanushek, Ludger Woessmann's study 'The Economic Impacts of Learning Losses', which is carried out within the framework of the OECD and which in turn is based on past studies about school closures and learning losses during the summer, future individual income losses will equate to about $1.9 \%$ during a lifetime. The average monthly salary in Georgia was 1,204 GEL (\$377.2 / € 346) in 2019. Using this data, an individual loss will be on average $\$ 86$ per year.))

This is not a big number at first glance, but if we recalculate this on the number of students who were affected by learning losses $(528,426$ students were registered in the general education system by March 2020), the total one-year loss is quite large - $\$ 45,444,636$. If we also take into account that the average working period for a person is 45 years, then under the conditions of the $3 \%$ discount rate, the present value of the income lost by 1 student will be approximately $\$ 2,109$. This suggests that the next generation will have to pay quite a high price due to covid-19)).

According to the same study, Georgia will lose $1.1 \%$ of the country's future GDP due to a 40 day study loss in the spring of 2020 , which is $69 \%$ of the country's current GDP. If the delays continue, suppose, during six months, Georgia will have a next $2.9 \%$ decline in GDP, equivalent to $136 \%$ of our current GDP. Over time, these losses will be from $\$ 12,049$ million to $\$ 23,796$ million. Georgia's GDP in 2019 was 17,477.26 million US dollars.

However, as mentioned above, the same learning loss has different effects in different countries, just as the impact of education on individuals' incomes varies according to the level

\footnotetext{
${ }^{1}$ For the current 2021 fiscal year, upper middle-income economies are those with a GNI per capita
} between $\$ 4,046$ and $\$ 12,535$ 
of development of countries. In countries with highly developed economies, education is highly valued.

Generally, education on healthy labor markets increases the chances of employment, but this is not the case in Georgia. We have the opposite relationship between education level and employment rate. Higher education in Georgia slightly increases employment opportunities and increases pay by $26 \%$ compared to general education, which is significantly lower than the average of OECD countries (56\%) (Galt \& Taggart, 2020). One of the main reasons for this is the lack of knowledge and skills relevant to the market requirements which indicates the low quality of general, professional, and higher education and which we talked about above.

Given this, we think that the loss of education caused by the closure of schools caused by the pandemic will worsen the quality of education and reduce the incomes of the already poor population, although this reduction will not be as large as in the countries with developed economies and the decline in individual income and GDP may be much smaller than in our calculations made above (Tea Kasradze, 2015). Deterioration of the economic situation of both individuals and the country as a whole is inevitable in the short run but it should also be noted that the experience and technical skills acquired during the pandemic may have a positive impact on the incomes of future generations.

\section{Summary and Recommendations}

Due to the situation created by the new coronavirus pandemic, educational institutions switched to distance learning mode from March 2019-2020. Learning losses are precisely associated with distance learning. The damage caused by learning losses can be devastating for the country. Unfortunately, distance learning in Georgia is not a perfect alternative to the learning process because many students, schoolchildren, and even teachers do not have access to the Internet, computer, and relevant skills to use it.

Learning losses are present in Georgia today. There is a need for the government, particularly the Ministry of Education, to transparently collect information about students' academic achievement, social and emotional well-being due to the pandemic, identify learning losses, investigate the causes and find ways to eliminate the losses.

Surveys of students, their parents, and teachers show that the level of students' knowledge in Georgia is quite low. The level of teacher training is also often critically assessed. The knowledge level obtained through distance learning in Georgia and the level of distance learning conducted by teachers are also assessed with 5 points in both cases under the 10point grading system. It means that students have mastered this or that discipline, crossed the minimum threshold, but this is not a quality education that will help them win in competitions and help them establish a place in the labor market.

The Government of Georgia has managed to shift the schools, closed due to the Covid-19 pandemic, to the remote mode in the shortest possible time, thus ensuring the continuity of teaching, but distance learning quality requires more attention. The methods and tools used in the online learning process also require extra attention from educational leaders, especially when school students have different technological, economic and social opportunities. It is necessary to evaluate how this or that online teaching method is better than the other. Do these methods lead the students to results? Are students taught through innovative methods? 
Currently, face-to-face teaching in schools has been partially restored, but if the community is not vaccinated on time, the schools may close again. Which will further complicate the situation in the future. Discontinuation of education at educational institutions will have serious negative long-term consequences for both the economy and well-being of society inequality will deepen, human health will deteriorate, and social ties and relationships will weaken.

Learning losses are especially high in vulnerable groups, as distance learning has further increased the problem of access to education for this category of students. Therefore there is a high risk that we will get an even more polarized student community after the schools are fully open. Many students may even refuse to attend school. This problem requires special attention from the state. Additional funding is needed to set up a tutoring teacher institute that will work individually with such students and facilitate their re-socialization. The tutoring teacher institute will help these children not to be left out of the learning process forever. The state must take care of them and create equal conditions for learning. The state role needs to be enhanced across countries, although special importance should be given to education support at the regional level.

\section{Bibliography}

[1] (2020). Retrieved from Action against hunger: https://www.actionagainsthunger.org/global-poverty-hunger-facts

[2] Belot, M., \& Webbink, D. (2010). Do Teacher Strikes Harm Educational Attainment of Students? LABOUR, Volume 24(Issue 4).

[3] Data for the Sustainable Development Goals. (2017). Retrieved from http://uis.unesco.org/en/news/6-out-10-children-and-adolescents-are-notlearning-minimum-reading-and-math

[4] Galt \& Taggart. (2020). Education sector in Georgia. https://galtandtaggart.com/upload/reports/14673.pdf

[5] Gulua, E. (2017 Gmol April-June). Modern Challenges of Higher Education. Economics and Business, $\mathrm{X}(2)$.

[6] Hanushek, E. A., \& Woessmann, L. (2020). The Economic Impacts of Learning Losses. OECD Education Working Paper(225). Paris: OECD Publishing. doi:https://doi.org/10.1787/21908d74-e

[7] Ichino, A., \& Winter-Ebmer, R. (2004). The Long-Run Educational Cost of World War II. Journal of Labor Economics , 22(1). Retrieved from https://uh.edu/ adkugler/Ichino\%26Winter-Ebmer.pdf

[8] IDFI. (2020). Internet access and use trends in Georgia. IDFI. https://idfi.ge/public/upload/Covid/Internet_access_and_use_in_Georgia.pdf-œs6

[9] ILO. (2020). ILO Monitor: COVID-19 and the world of work. Fourth edition Updated estimates and analysis. International Labour Organisation. Retrieved from https://www.ilo.org/wcmsp5/groups/public/---dgreports/--dcomm/documents/briefingnote/wcms_745963.pdf 
[10] Kasradze, T. (2018). Trends of Financing for Development in Georgia. American Scientific Journal \#21 „32-40.

[11] Kasradze, T., \& Zarnadze, N. (2019). Challenges of Economic of Georgia: Good and Bad Economic Growth. European Journal of Economics and Business Studies, 178186.

[12] Kasradze, Tea; Antia, Vakhtang; Gulua, Ekaterine. (2019). Challenges of Financial Management of the Higher Education Institutions in Georgia. European Journal of Economics and Business Studies, 187-206.

[13] Kuhfeld, M., Soland, J., Tarasawa, B., Johnson, A., Ruzek, E., \& Liu, J. (2020). Projecting the Potential Impact of COVID-19 School Closures on Academic Achievement. Educational Researcher (ER). doi:https://doi.org/10.3102/0013189X20965918

[14] Ministry of Education, Science, Culture and Sports of Georgia. (2020). Pandemic and General Education in Georgia. Retrieved from http://mes.gov.ge/mesgifs/1609844890_2020-Annual-report-ENG.pdf

[15] Out-of-School Children and Youth. (2018). Retrieved from Data for the Sustainable Development Goals: http://uis.unesco.org/en/topic/out-school-children-andyouth\#: :text=About $\% 20258 \% 20$ million\%20children $\% 20$ and,million $\% 20$ of $\% 20 u$ pper\%20secondary\%20age.

[16] Psacharopoulos, G., Patrinos, H., Collis, V., \& Vegas, E. (2020). The COVID-19 cost of school closures. Brookings. Retrieved from https://www.brookings.edu/blog/education-plus-development/2020/04/29/thecovid-19-cost-of-school-closures/

[17] Reimers, Fernando M.; Schleicher, Andreas. (2020). A framework to guide an education response to the COVID-19 Pandemic of 2020. Retrieved from https://globaled.gse.harvard.edu/files/geii/files/framework_guide_v2.pdf?fbclid=I wAR3VaISFpcI-KHMXFf5McAcRPuXodXrjQ84VINsVA4u7asJkFl1fAXH6SWE

[18] Tea Kasradze. (2015). Theoretical Aspects of Financial Crises. Proceedings of Materials of International Scientific-Practical Conference ACTUAL PROBLEMS OF SUSTAINABLE DEVELOPMENT OF NATIONAL ECONOMIES (33. 335-337). Tbilisi: PUBLISHING HOUSE OF PAATA GUGUSHVILI INSTITUTE OF ECONOMICS OF IVANE JAVAKHISHVILI TBILISI STATE UNIVERSITY. http://www.pgie.tsu.ge/contentimage/konferenciebi/2015_pdf

[19] Tea, Kasradze. (2013). Poverty - A Global Socio-Economic Problem. Caucasus International University HERALD \#5, pp. 15-18.

[20] UNICEF. (2020). How many children and young people have internet access at home? Estimating digital connectivity during the COVID-19 pandemic. New York: UNICEF. Retrieved from https://www.unicef.org/georgia/media/5701/file/children $\% 20$ and $\% 20$ access $\% 20$ to\%20internet.pdf 
[21] Unicef for every child. (2020, November 30). Retrieved from https://www.unicef.org/press-releases/two-thirds-worlds-school-age-childrenhave-no-internet-access-home-new-unicef-itu

[22] Wawrosz, P., \& Mihola, J. (2013, December). THE SHARE OF INTENSIVE AND EXTENSIVE FACTORS ON THE GDP DEVELOPMENT OF SELECTED EU COUNTRIES. European Scientific Journal \#1, pp. 215-221.

[23] Zarnadze, N., \& Kasradze, T. (2019). A WEAK EDUCATION SYSTEM -A CHALLENGE FOR SOCIETY'S WELL-BEING. Journal of Teaching and Education, 137-149. Retrieved from http://www.universitypublications.net/jte/0901/pdf/H9V378.pdf

[24] Zarnadze, Nino; Kasradze, Tea. (2020). Strong Organizational Culture - An Effective Tool for Companies to Survive in a Pandemic World. European Journal of Language and Literature Studies, 6(2). Retrieved from http://journals.euser.org/files/articles/ejls_v6_i2_20/Zarnadze.pdf 